\title{
Resistance among New Prunus Rootstocks and Selections to Root-knot Nematodes in Spain and France
}

\author{
Carolina Fernández ${ }^{1}$ and Jorge Pinochet ${ }^{2}$ \\ Departamento de Patología Vegetal, Institut de Recerca $i$ Tecnologia \\ Agroalimentàries, Crta. de Cabrils s/n 08348, Cabrils, Barcelona, Spain
}

Daniel Esmenjaud ${ }^{2}$

Laboratoire de Biologie des Invertébrés, Institut National de la Recherche Agronomique, B.P. 2078, 06606 Antibes Cedex, France

George Salesses ${ }^{3}$

Station de Recherches Frutierès, Institut National de la Recherche Agronomique, B.P. 81, 33883 Villenave d'Ornon Cedex, France

Antonio Felipe ${ }^{3}$

Servicio de Investigación Agraria, Apartado 727, 50080 Zaragoza, Spain

Additional index words. Meloidogyne arenaria, M. javanica, M. incognita, Prunus, resistance, rootstocks

\begin{abstract}
New Prunus rootstocks and selections were evaluated for their reaction to Meloidogyne arenaria (Neal) Chitwood, M. incognita (Kofoid \& White Chitwood), or $M$. javanica (Treub) Chitwood. Most of the clones were peach-almond hybrids (P-AHs) $[P$. persica (L.) Batsch X P. dulcis (Mill.) D.A. Webb] or plums of Spanish and French origin. In a first experiment, the P-AH Hansen 2-168 and plums GF-31 (P. cerasifera Ehr.) and GF 8-1 (P. cerasifera $X$ P. munsoniana Weigth et Hedr.) were highly resistant to the mixture of five isolates of $M$. javanica. The P-AHs Barrier and Titan $x$ Nemared were resistant and moderately resistant, respectively; GF-677, MB 3-13, MB 2-2, and MB 2-6 were susceptible. In the second and third experiment, the plums P 1079, $P$ 2175, the hybrids Afgano (P. dasycarpa Ehrh.), G X N No 22, and G X N No 15, both P-AHs, and Nemared peach were highly resistant to mixtures of five isolates of $M$. incognita or $M$. arenaria. The plums $P 2980$ (P. cerasifera) and GF 8-1 tested against either root-knot species were also highly resistant. Cachirulo $\times$ (G $\times$ N No 9), a P-AH, showed less resistance to $M$. arenaria than to $M$. incognita. Montclar (P. persica) and the P-AHs Torrents AC and GF-677 were susceptible to both species.
\end{abstract}

The Meloidogyne spp. are common in nurseries and Prunus orchards in Spain and in southern France (De Guiran, 1993; García de Otazo, 1992; Pinochet et al., 1992; Scotto La Massese, 1989). Losses caused by root-knot nematodes in peach, plum (Prunus spp.), and almond [P. dulcis (Mill.) Webb] production are unknown, although they are likely to be similar to those that occur in other production areas that share similar environmental and agronomic conditions (Lamberti, 1981; McKenry, 1989; Nyczepir, 1991). Root-knotresistant rootstocks that are available commercially, such as Nemaguard, Hansen 2-168, Titan X Nemaguard, Nemared, and Saint Julien

Received for publication 6 Dec. 1993. Accepted for publication 4 Mar. 1994. This work was financed by the Spanish Instituto Nacional de Investigaciones Agrarias, Grant no. SC92-132, and the Commission of European Communities AIR CT 920312. The cost of publishing this paper was defrayed in part by the payment of page charges. Under postal regulations, this paper therefore must be hereby marked advertisement solely to indicate this fact.

${ }^{1}$ Graduate Assistant.

${ }^{2}$ Research Nematologist.

${ }^{3}$ Plant Breeder.
655-2, do not always adapt well to Mediterranean growing conditions, suffering badly from iron chlorosis, root asphyxia, and root diseases (Felipe, 1989; Socías, 1990).

In the last decade, a significant effort has been made in Spain and France to incorporate resistance against root-knot nematodes into new Prunus rootstocks, mainly peach-almond hybrids (P-AHs) and plums (Bernhard et al., 1985; Felipe et al., 1990). These are replacing widely used seedling stocks, which, in general, lack homogeneity and are susceptible to root-knot nematodes. Several interesting genotypes in their late stages of selection from breeding programs of Spanish and French research centers have shown a high degree of resistance with single isolate inoculations (Esmenjaud et al., 1994; Marull et al., 1991; Pinochet et al., 1989). Nevertheless, the responses of new advanced breeding lines, as well as new commercial introductions to this pest, are not known. The high intraspecific variability in Meloidogyne spp. clearly indicates the need for testing plant material to several populations of the same species to assure broad resistance (Esmenjaud et al., 1994). To achieve this goal, inoculations with mixed populations of the same root-knot species were performed. This investigation was conducted under greenhouse conditions to determine the comparative reaction of 19 experimental and commercial Prunus rootstocks to the three most common root-knot nematode species in the Mediterranean region, Meloidogyne arenaria, $M$. incognita, and $M$. javanica.

\section{Materials and Methods}

Seeds, herbaceous and hardwood cuttings, and micropropagated material were supplied by public research institutes and private sources in Spain and France. The main horticultural features of each rootstock are given in Table 1 . Seeds of the peach rootstocks Nemared, Montclar, and P-AH Titan $x$ Nemared were treated with a $5 \%$ solution of copper oxychloride for $24 \mathrm{~h}$, rinsed with running water, covered with a moist paper towel, and stratified in perlite on trays that were kept in a storage room at $4 \mathrm{C}$ for 45 days. Then, seed material was moved to ambient temperature in a greenhouse to induce germination. Herbaceous and hardwood cuttings of $\mathrm{G} \times \mathrm{N}$ No 15 , $\mathrm{G} \times \mathrm{N}$ No 22, MB 2-2, MB 2-6, MB 3-13, Cachirulo $\times(\mathrm{G} \times \mathrm{N}$ No 9), and Afgano were treated for 6 to $10 \mathrm{sec}$ with a $50 \%$ ethanol solution that contained $2000 \mathrm{ppm}$ of indole butyric acid (Hansen and Hartman, 1967). Cuttings then were planted in small pots (200 $\left.\mathrm{cm}^{3}\right)$ containing a 3 sand : 1 peat mixture $(\mathrm{v} / \mathrm{v})$ previously pasteurized at $80 \mathrm{C}$. Micropropagated P-AHs GF-677, Barrier, Torrents AC, Hansen 2-168, and plums GF-31 and GF 8-1 were received as plantlets from Agromillora Catalana S.A., Sant Sadurní d'Anoia, Barcelona, Spain; transferred from agar to 50$\mathrm{cm}^{3}$ minipots with peat substrate; and climatized in a high-humidity chamber for 24 days. The micropropagated plums P 1079, P 2175 , and $P 2980$ were supplied bare root from the Fruit Breeding Stations of the Institut National de la Recherche Agronomique in Bordeaux and Avignon, France.

Plantlets with uniform growth arising from germinated seeds, rooted cuttings, and micropropagated material were transplanted to 3-liter containers filled with a pasteurized sandy loam-textured soil ( $84 \%$ sand, $14 \%$ silt, $2 \%$ clay) with $\mathrm{pH} 7.3,<2 \%$ organic matter, and a cation-exchange capacity $<10 \mathrm{meq} / 100$ $\mathrm{g}$ soil. Plants were kept in the greenhouse for 6 weeks before inoculation.

Three root-knot nematode species (five isolates per species) were originally collected from various hosts (mainly Prunus) and geographical localities (Table 2). Isolates were increased on tomato (Lycopersicon esculentum Mill. cv. 'Redondo Liso') from single-egg-mass cultures. Identification of isolates was made by perineal patterns ( 20 females per population) and confirmed by random amplified polymorphic DNA technique (Cenis, 1993). In cases of discrepancy in species identification between methods, the molecular technique was considered as a more reliable identification criterion. To assure a desired pathogenic diversity for testing plant material (Marull et al., 1994, Scotto La Massese et al., 1984), 
Table 1. Information of 19 Prunus rootstocks and selections evaluated against Meloidogyne arenaria, M. incognita, and $M$. javanica.

\begin{tabular}{|c|c|c|c|}
\hline Rootstock & Species/selection & Origin $^{z}$ & Main horticultural features \\
\hline GF-677 & Natural peach-almond hybrid & INRA, France & $\begin{array}{l}\text { Good vigor, high compatibility, } \\
\text { and resistant to iron chlorosis }\end{array}$ \\
\hline $\mathrm{G} \times \mathrm{N}$ No 15 & Peach-almond hybrid & SIA, Spain & $\begin{array}{l}\text { Good vigor, easy propagation, and } \\
\text { resistant to } M \text {. arenaria, } M \text {. } \\
\text { incognita, and } M \text {. javanica }\end{array}$ \\
\hline $\mathrm{G} \times \mathrm{N}$ No 22 & Peach-almond hybrid & SIA, Spain & $\begin{array}{l}\text { Good vigor, resistant to iron } \\
\text { chlorosis and } M \text {. javanica }\end{array}$ \\
\hline Hansen 2-168 & Peach-almond hybrid & $\begin{array}{l}\text { Univ. of Calif., } \\
\text { USA }\end{array}$ & $\begin{array}{l}\text { Good vigor, easy propagation, and } \\
\text { resistant to } M \text {. arenaria, } \\
M \text {. incognita, and } M \text {. javanica }\end{array}$ \\
\hline Barrier & $P$. persica $\times P$. davidiana & $\begin{array}{l}\text { Univ. of Florence, } \\
\text { Italy }\end{array}$ & $\begin{array}{l}\text { Good vigor, early production, } \\
\text { resistant to Meloidogyne spp., } \\
\text { and cold sensitive }\end{array}$ \\
\hline Torrents AC & Natural peach-almond hybrid & AC, Spain & $\begin{array}{l}\text { Medium vigor and increased } \\
\text { fruit size }\end{array}$ \\
\hline \multicolumn{4}{|l|}{ Cachirulo $\mathrm{x}$} \\
\hline (G x N No 9) & Peach-almond hybrid & SIA, Spain & $\begin{array}{l}\text { Medium vigor, red leaf, and easy } \\
\text { propagation }\end{array}$ \\
\hline MB 2-2 & Peach-almond hybrid & IRTA, Spain & $\begin{array}{l}\text { Good vigor and easy } \\
\text { propagation }\end{array}$ \\
\hline MB 2-6 & Peach-almond hybrid & IRTA, Spain & $\begin{array}{l}\text { Good vigor and easy } \\
\text { propagation }\end{array}$ \\
\hline MB 3-13 & Peach-almond hybrid & IRTA, Spain & $\begin{array}{l}\text { Good vigor and easy } \\
\text { propagation }\end{array}$ \\
\hline \multicolumn{4}{|l|}{ Titan $x$} \\
\hline Nemared & Peach-almond hybrid & $\begin{array}{l}\text { USDA, Calif., } \\
\text { USA }\end{array}$ & $\begin{array}{l}\text { Medium vigor, irregular in } \\
\text { development, and resistant to } \\
\text { Meloidogyne spp. }\end{array}$ \\
\hline Nemared & P. persica & USDA, USA & $\begin{array}{l}\text { Red leaf, resistant to } M \text {. arenaria, } \\
M \text {. hapla, } M \text {. incognita, and } \\
\text { M. javanica }\end{array}$ \\
\hline Montclar & P. persica & INRA, France & $\begin{array}{l}\text { Good vigor and good } \\
\text { compatibility }\end{array}$ \\
\hline GF 8-1 & P. marianna & INRA, France & Resistant to root asphixia \\
\hline P 1079 & P. cerasifera & INRA, France & $\begin{array}{l}\text { Good vigor, resistant to } \\
\text { M. arenaria, } M \text {. hapla, } \\
\text { M. hispanica, } \text { M. incognita, and } \\
\text { M. javanica. Low } \\
\text { compatibility with peach } \\
\quad \text { varieties }\end{array}$ \\
\hline P 2175 & P. cerasifera & INRA, France & $\begin{array}{l}\text { Good vigor, resistant to } \\
M \text {. arenaria, } M \text {. hapla, } \\
M \text {. hispanica, } M \text {. incognita, } \\
\text { and } M \text {. javanica. Good } \\
\text { compatibility with most } \\
\text { peach varieties }\end{array}$ \\
\hline P 2980 & P. cerasifera & INRA, France & $\begin{array}{l}\text { Good vigor, resistant to } \\
M . \text { arenaria, } M \text {. hispanica, } \\
M \text {. incognita, and } M \text {. javanica. } \\
\text { Good compatibility with most } \\
\text { peach varieties }\end{array}$ \\
\hline GF-31 & P. cerasifera $\times$ P. salicina & INRA, France & $\begin{array}{l}\text { Good compatibility with apricot } \\
\text { varieties }\end{array}$ \\
\hline Afgano & P. dasycarpa & SIA, Spain & $\begin{array}{l}\text { Easy propagation, resistant to iron } \\
\text { chlorosis and drought }\end{array}$ \\
\hline
\end{tabular}

"INRA = Institut National de la Recherche Agronomique; SIA = Servicio de Investigación Agraria; AC = Agromillora Catalana; IRTA = Institut de Recerca i Tecnologia Agroalimentàries; USDA = U.S. Dept. of Agriculture.

inoculum for each nematode species consisted of a mixture of five isolates that included 1000 nematodes from each isolate (5000 nematodes per plant). Simultaneously to the Prunus inoculations, 1000 nematodes from each isolate were inoculated separately onto four 'Roma' tomato plants to confirm the infectivity of each isolate at inoculation time.

Three experiments were conducted, one in 1992 and two in 1993. The reaction of the Prunus rootstocks Barrier, Titan $\times$ Nemared, Hansen 2-168, MB 2-2, MB 2-6, MB-3-13, GF-677, GF-31, and GF 8-1 against a mixture of five isolates of M.javanica were evaluated in the first experiment (1992). The P-AHs Hansen 2-168 and GF-677 were used as resistant and susceptible reference rootstocks, respectively. Plants with uniform growth of $\approx 30$ $\mathrm{cm}$ in height ( 25 to 30 leaves) were inoculated with a suspension of 5000 eggs per plant through four holes in the soil, $3 \mathrm{~cm}$ from the base of the plant. Inoculum of each isolate was prepared by macerating infested tomato roots in a blender for $10 \mathrm{sec}$ in a $0.12 \%$ to $0.15 \%$ solution of $\mathrm{NaOCl}$ to disperse egg masses. Eggs were concentrated in a $25 \mu \mathrm{m}$-pore sieve (500 mesh) and rinsed with tap water before inoculation (Hussey and Barker, 1973).
In the second experiment, rootstocks $\mathrm{G} \times \mathrm{N}$ No 15, Gx N No 22, Cachirulox (G X N No 9), Torrents AC, GF-677, Afgano, Nemared, Montclar, P 1079, P 2175, and P 2980 were evaluated against a mixture of five isolates of $M$. incognita. In the third experiment, the rootstocks GXNNo 15, GxN No 22, Cachirulo x(GXN No 9), Torrents AC, Titan X Nemared, Afgano, Nemared, Montclar, P 1079, P 2175, and GF 8-1 were evaluated against a mixture of five isolates of $M$. arenaria. In both experiments conducted in 1993, Nemared and Montclar peach were used as resistant and susceptible reference rootstocks, respectively. Inocula and inoculation were prepared as described for the first experiment. Most of the rootstocks tested against $M$. javanica were not included in evaluations to $M$. arenaria or $M$. incognita, since they had already been tested (Marull et al., 1991) or were not worth testing due to high susceptibility to $M$. javanica.

Plants were harvested 120 days after inoculation. Total number of galls, final nematode population per plant (soil and roots), and the numbers of nematodes per gram of root were determined. Nematodes in soil were obtained by placing the soil from each container in a large pan. Roots were washed free of soil particles in a second pan with a known volume of water. Contents of both pans were mixed and stirred for $1 \mathrm{~min}$, and $250 \mathrm{~cm}^{3}$ of the resulting slurry was used as a sample (Marull and Pinochet, 1991). Nematodes then were extracted by differential sieving and sugar flotation (Jenkins, 1964). Nematode densities in the soil were calculated based on $250-\mathrm{cm}^{3}$ aliquots. Nematodes in roots were extracted in the same manner as was the inoculum, but the entire root system was weighed, cut into pieces with shears, and macerated in a blender at $14,500 \mathrm{rpm}$ in a stronger solution of $\mathrm{NaOCl}$ $(0.25 \%$ to $0.30 \%)$ for three periods of $15 \mathrm{sec}$ each, separated by two 5 -sec intervals. This extra blending was needed to free eggs and second-stage juveniles embedded in the lignified root tissue. Nematodes then were concentrated using $150-, 74-$, and $25-\mu \mathrm{m}$ pore sieves $(100,200$, and 500 mesh, respectively). Root tissue and debris collected on the 100-mesh sieve were discarded. The resistance rating of each rootstock was estimated according to nematode reproduction and root galling: $\mathrm{HR}=$ highly resistant (nematode may or may not invade root, but there was little or no reproduction); $\mathrm{R}=$ resistant (limited reproduction with final nematode population lower than initial; incipient galling); $\mathrm{MR}=$ moderately resistant (final population lower or slightly higher than initial; galling scarce, although noticeable); and $\mathrm{S}=$ susceptible (nematode densities increased rapidly, causing abundant galling).

Plants were watered daily or as needed and fertilized with a full-strength Hoagland's (Hoagland and Arnon, 1950) nutrient solution once a week. Experiments were conducted in a greenhouse with controlled temperature range ( 23 to 32C). Inoculated containers were placed in a sand bed to avoid temperature and humidity fluctuations. In all experiments, each material was replicated eight times in a completely randomized design. Data were analyzed by a 
Table 2. Information on host and geographic origin of 15 Meloidogyne isolates used for testing Prunus rootstocks.

\begin{tabular}{|c|c|c|}
\hline Isolate/species ${ }^{\mathrm{z}}$ & Host & Geographic origin \\
\hline \multirow[t]{5}{*}{ M. arenaria } & Carnation (Dianthus caryophillus L.) & Seville, Spain \\
\hline & Tomato (Lycopersicon esculentum) & Canet, Barcelona, Spain \\
\hline & Peach (Prunus persica) & Sastre, Tarragona, Spain \\
\hline & Peach & Abarán, Murcia, Spain \\
\hline & Peach & Mendoza, Argentina \\
\hline \multirow[t]{5}{*}{ M. incognita } & Peach & Caspe, Zaragoza, Spain \\
\hline & $\begin{array}{l}\text { Peach-almond hybrid } \\
\quad(P . \text { persica } \times P . \text { dulcis })\end{array}$ & $\begin{array}{l}\text { Villaverde del Río, Seville, } \\
\text { Spain }\end{array}$ \\
\hline & Plum (Prunus cerasifera) & Andújar, Jaen, Spain \\
\hline & Tomato & Provence, France \\
\hline & Tomato & Cayene, French Guayana \\
\hline \multirow[t]{5}{*}{ M. javanica } & Fig (Ficus carica L.) & Cabrils, Barcelona, Spain \\
\hline & Almond (Prunus dulcis) & Reus, Tarragona, Spain \\
\hline & Peach-almond hybrid & $\begin{array}{l}\text { San José de la Rinconada, Seville, } \\
\text { Spain }\end{array}$ \\
\hline & Unknown & California, USA \\
\hline & Peach & Anatolia, Turkey \\
\hline
\end{tabular}

${ }^{2}$ Isolates were identified by random amplified polymorphic DNA technique. one-way analysis of variance. Data for galling, final nematode population, and nematodes per gram of root data were $\log _{10}(\mathrm{x}+1)$ transformed. Means were compared by Tukey's multiple range test $(P \leq 0.05)$.

\section{Results and Discussion}

All tomato plants used for checking the viability of each isolate before mixing in aqueous suspension at inoculation time were heavily galled 60 days after inoculation, indicating that every isolate was highly infective.

In the first experiment, the $\mathrm{P}-\mathrm{AH}$ Hansen 2-168 and plums GF-31 and GF 8-1 were free of galls, and the final population (soil and roots) at 4 months after inoculation indicated a isolates of $M$. javanica (Table 3 ). These three rootstocks differed from the hybrids Titan $\mathrm{x}$ Nemared $(\mathrm{P}-\mathrm{AH})$ and Barrier $[P$. persica $\times P$. davidiana (Carr.) Franch.], which showed low galling and reproduction (although lower than the $\mathrm{Pi}$ ), indicating a lower level of resistance than Hansen 2-168, GF-31, and GF 8-1. However, the relative differences in resistance between Hansen 2-168, GF-31, GF 8-1 vs. Titan $x$ Nemared and Barrier would appear to be minimal in terms of field performance. These three rootstocks (Hansen 2-168, GF-31, and GF 8-1) also differed from Titan $x$ Nemared, but not from Barrier in the number of nematodes per gram of root. The susceptible control rootstock GF-677 and the experimental P-AHs MB 2-2, MB 2-6, and MB 3-13 showed a high level of susceptibility, with abundant galling and nematode reproduction. MB 2-6 reached the highest level of parasitism in this study (Table 3).

In the second experiment using inoculation with $M$. incognita, the Prunus rootstocks Afgano, Nemared, P 1079, P 2175, P 2980, G $x$ N No $15, G \times$ N No 22, and Cachirulo $x$ (G $x \mathrm{~N}$ No 9) were highly resistant to the nematode, whereas GF-677, Montclar, and Torrents AC showed different degrees of susceptibility (Table 4).

In the third experiment (inoculation with M. arenaria), the rootstocks Afgano, Nemared, high level of resistance to the mixture of five
P 1079, P 2175, GF 8-1, G x N No 15, G x N No 22, and Titan $x$ Nemared showed a highly resistant response (Table 5). The $\mathrm{P}-\mathrm{AH}$ Cachirulo $x$ ( $\mathrm{G} \times \mathrm{N}$ No 9) was moderately resistant, while Montclar and Torrents AC were susceptible. Nemared and Cachirulo $\mathrm{X}$ (GXN No 9) presented some galling, although in the case of Nemared, nematode reproduction was suppressed, whereas in the $\mathrm{P}-\mathrm{AH}$ Cachirulo $\times(\mathrm{G} \times \mathrm{N}$ No 9) reproduction was low. In these two experiments, the nine rootstocks evaluated to $M$. incognita and $M$. arenaria mixtures (but not mixtures of both species) showed a similar response to both species except that Cachirulo $\times(G \times N$ No 9) was less resistant to the mixture of $M$. arenaria isolates. Perhaps one or several isolates in this mixture were capable of attacking this rootstock.

Occasionally, third- and fourth-stage juveniles ( $\mathrm{J} 3$ and $\mathrm{J} 4$ ) of $M$. arenaria and $M$. incognita were detected in root tissues of $\mathrm{G} \times \mathrm{N}$ No $15, \mathrm{G} \times \mathrm{N}$ No 22 , P 1079, and GF 8-1 in the absence of galling, indicating that penetration and minor development took place. However, nematode development appeared to be suppressed, as with other Prunus rootstocks that are root-knot-nematode resistant (Malo, 1967; Marull et al., 1994).

The plums P 1079 and P 2175 had been previously tested in France against singleisolate inoculations to a wide range of populations belonging to $M$. arenaria, $M$. incognita, M. hapla Chitwood, M. hispanica Hirschmann, and M. javanica (Esmenjaund et al., 1993; Esmenjaud et al., 1994). The expression of resistance in Prunus rootstocks infected with Meloidogyne spp. can be affected by high soil temperatures (Canals et al., 1992; Fernández et al., 1993; Wehunt, 1972). In this study, both plum rootstocks were evaluated under higher temperature regimes than those in France, but they maintained their high level of resistance and broad resistance to a mixture of root-knot nematodes. This study also confirms the broad resistance of G X N No 15 (Marull et al., 1994) and provides new information on the high level of resistance of $\mathrm{G} \times \mathrm{N}$ No 22, a selection
Table 3. Galling and reproduction of Meloidogyne javanica on nine Prunus rootstocks or selections 120 days after inoculation with 5000 nematodes per plant.

\begin{tabular}{lcccc}
\hline & $\begin{array}{c}\text { Final nematode } \\
\text { population } \\
\text { Rootstock or selection }\end{array}$ & $\begin{array}{c}\text { zo. } \\
\text { galls/plant }\end{array}$ & $\begin{array}{c}\text { Nematodes/ } \\
\text { (soil and roots) }\end{array}$ & $\begin{array}{c}\text { Resistance } \\
\text { rating }^{\mathrm{y}}\end{array}$ \\
\hline Hansen 2-168 & $0 \mathrm{a}$ & $0 \mathrm{a}$ & $0 \mathrm{a}$ & $\mathrm{HR}$ \\
GF-31 & $0 \mathrm{a}$ & $0 \mathrm{a}$ & $0 \mathrm{a}$ & $\mathrm{HR}$ \\
GF 8-1 & $0 \mathrm{a}$ & $0 \mathrm{a}$ & $0 \mathrm{a}$ & $\mathrm{HR}$ \\
Barrier & $13 \mathrm{~b}$ & $440 \mathrm{~b}$ & $20 \mathrm{ab}$ & $\mathrm{R}$ \\
Titan x Nemared & $8 \mathrm{~b}$ & $2,820 \mathrm{~b}$ & $350 \mathrm{~b}$ & MR \\
GF-677 & $116 \mathrm{c}$ & $16,680 \mathrm{c}$ & $1,220 \mathrm{c}$ & $\mathrm{S}$ \\
MB 3-13 & $129 \mathrm{c}$ & $23,630 \mathrm{c}$ & $5,440 \mathrm{~cd}$ & $\mathrm{~S}$ \\
MB 2-2 & $76 \mathrm{c}$ & $33,970 \mathrm{c}$ & $8,250 \mathrm{~d}$ & $\mathrm{~S}$ \\
MB 2-6 & $80 \mathrm{c}$ & $77,330 \mathrm{c}$ & $23,630 \mathrm{~d}$ & $\mathrm{~S}$
\end{tabular}

${ }^{2}$ Data are means of eight replications. Actual data are presented, but data were transformed to $\log _{10}(\mathrm{x}+1)$ for analysis. Mean separation in columns by Tukey's multiple range test $(P \leq 0.05)$.

${ }^{y} \mathrm{HR}=$ highly resistant; $\mathrm{R}=$ resistant; $\mathrm{MR}=$ moderately resistant; $\mathrm{S}=$ susceptible.

Table 4. Galling and reproduction of Meloidogyne incognita on 11 Prunus rootstocks or selections 120 days after inoculation with 5000 nematodes per plant.

\begin{tabular}{|c|c|c|c|c|}
\hline Rootstock or selection $^{2}$ & $\begin{array}{l}\text { No. } \\
\text { galls/plant }\end{array}$ & $\begin{array}{c}\text { Final nematode } \\
\text { population } \\
\text { (soil and roots) }\end{array}$ & $\begin{array}{c}\text { Nematodes/ } \\
\text { g root }\end{array}$ & $\begin{array}{c}\text { Resistance } \\
\text { rating }^{y}\end{array}$ \\
\hline Afgano & $0 \mathrm{a}$ & $0 \mathrm{a}$ & $1 \mathrm{a}$ & HR \\
\hline Nemared & $0 \mathrm{a}$ & $0 \mathrm{a}$ & $0 \mathrm{a}$ & HR \\
\hline P 1079 & $0 \mathrm{a}$ & $0 \mathrm{a}$ & $0 \mathrm{a}$ & HR \\
\hline P 2175 & $0 \mathrm{a}$ & $0 \mathrm{a}$ & $0 \mathrm{a}$ & HR \\
\hline P 2980 & $0 \mathrm{a}$ & $0 \mathrm{a}$ & $0 \mathrm{a}$ & $\mathrm{HR}$ \\
\hline $\mathrm{G} \times \mathrm{N}$ No 15 & $0 \mathrm{a}$ & $20 \mathrm{a}$ & $3 a$ & HR \\
\hline $\mathrm{G} \times \mathrm{N}$ No 22 & $0 \mathrm{a}$ & $10 \mathrm{a}$ & $2 a$ & HR \\
\hline Cachirulo $\times(G \times N$ No 9$)$ & $1 \mathrm{a}$ & $17 \mathrm{a}$ & $0 \mathrm{a}$ & HR \\
\hline GF-677 & $121 \mathrm{~b}$ & $4,650 \mathrm{~b}$ & $510 \mathrm{~b}$ & $\mathrm{~S}$ \\
\hline Montclar & $186 \mathrm{c}$ & $14,300 \mathrm{~b}$ & $3,660 \mathrm{bc}$ & S \\
\hline Torrents AC & $185 \mathrm{c}$ & $58,780 \mathrm{~b}$ & $5,490 \mathrm{c}$ & $\mathrm{S}$ \\
\hline
\end{tabular}

${ }^{2}$ Data are means of eight replications. Actual data are presented, but data were transformed to $\log _{10}(\mathrm{x}+1)$ for analysis. Mean separation in columns by Tukey's multiple range test $(P \leq 0.05)$.

${ }^{y} \mathrm{HR}=$ highly resistant; $\mathrm{S}=$ susceptible. 
Table 5. Galling and reproduction of Meloidogyne arenaria on 11 Prunus rootstocks or selections 120 days after inoculation with 5000 nematodes per plant.

\begin{tabular}{|c|c|c|c|c|}
\hline Rootstock or selection $^{2}$ & $\begin{array}{c}\text { No. } \\
\text { galls/plant }\end{array}$ & $\begin{array}{c}\text { Final nematode } \\
\text { population } \\
\text { (soil and roots) }\end{array}$ & $\begin{array}{c}\text { Nematodes/ } \\
\text { g root }\end{array}$ & $\begin{array}{c}\text { Resistance } \\
\text { rating }^{\mathrm{y}}\end{array}$ \\
\hline Afgano & $0 \mathrm{a}$ & $0 \mathrm{a}$ & $1 \mathrm{a}$ & HR \\
\hline Nemared & $6 \mathrm{ab}$ & $50 \mathrm{a}$ & $0 \mathrm{a}$ & HR \\
\hline P 1079 & $0 \mathrm{a}$ & $0 \mathrm{a}$ & $0 \mathrm{a}$ & HR \\
\hline P 2175 & $0 \mathrm{a}$ & $198 \mathrm{a}$ & $10 \mathrm{ab}$ & HR \\
\hline GF 8-1 & $0 \mathrm{a}$ & $32 \mathrm{a}$ & $3 a b$ & HR \\
\hline $\mathrm{G} \times \mathrm{N}$ No 15 & $0 \mathrm{a}$ & $58 \mathrm{a}$ & $1 \mathrm{a}$ & HR \\
\hline G x N No 22 & $0 \mathrm{a}$ & $100 \mathrm{a}$ & $2 \mathrm{a}$ & HR \\
\hline Titan $\times$ Nemared & $1 \mathrm{ab}$ & $50 \mathrm{a}$ & $4 \mathrm{ab}$ & HR \\
\hline Cachirulo $\times(\mathrm{G} \times \mathrm{N}$ No 9) & $5 \mathrm{~b}$ & $1,210 \mathrm{a}$ & $220 \mathrm{~b}$ & MR \\
\hline Montclar & $138 \mathrm{c}$ & $11,420 \mathrm{~b}$ & $690 \mathrm{c}$ & $\mathrm{S}$ \\
\hline Torrents AC & $117 \mathrm{c}$ & $28,070 \mathrm{~b}$ & $2,640 \mathrm{c}$ & $\mathrm{S}$ \\
\hline
\end{tabular}

${ }^{2}$ Data are means of eight replications. Actual data are presented, but data were transformed to $\log _{10}(\mathrm{x}+1)$ for analysis. Mean separation in columns by Tukey's multiple range test $(P \leq 0.05)$.

${ }^{\mathrm{y}} \mathrm{HR}=$ highly resistant; $\mathrm{MR}=$ moderately resistant; $\mathrm{S}=$ susceptible.

that has also proved to adapt well to very calcareous soils. Both $\mathrm{G} \times \mathrm{N}$ selections derive from crosses between Nemared peach (Ramming and Tanner, 1983) and the Spanish almond Garfí (Felipe et al., 1990).

We conclude that several new Prunus rootstocks and selections, especially plums (Afgano, P 1079, and P 2175) and P-AHs (Titan X Nemared, G X N No 15, G x N No 22), have desirable resistance to at least two common species of Meloidogyne, and they offer an effective control alternative to this pest. Although Barrier and P 2980 were tested only against one root-knot species, they showed a good level of resistance. The majority of these materials also are well adapted agronomically to warm Mediterranean environments (Felipe et al., 1990). A few are available commercially, while others are in late stages of selection.

\section{Literature Cited}

Bernhard, R., A. Bouquet, and C. Scotto la Massese. 1985. Diversité des problèmes nématologiques en vergers et en vignobles, solutions chemiques et génétiques. Comptes Rendus Acad. Agr. de France 71:707-719.

Canals, J., J. Pinochet, and A. Felipe. 1992. Temperature and age of plant affect resistance in peach-almond hybrid rootstock infected with Meloidogyne javanica. HortScience 27:12111213.

Cenis, J.L. 1993. Identification of four major Meloidogyne spp. by random amplified polymorphic DNA (RAPD-PCR). Phytopathology 83:76-78.

De Guiran, G. 1993. Protection des cultures maraîchères et frutierès fare aux capacités d'adaptation des nématodes Meloidogyne. Comptes Rendus Acad. Agr. de France 79:71-78.

Esmenjaud, D., J.C. Minot, R. Voisin, J. Pinochet, and G. Salesses. 1994. Inter- and intraspecific variability in plum, peach, and peach-almond rootstocks using 22 root-knot nematode populations. J. Amer. Soc. Hort. Sci. 119:94-100.

Esmenjaud, D., J.C. Minot, R. Voisin, G. Salesses, R. Poupet, and J.P. Onesto. 1993. Assessment of a method using plantlets grown previously in vitro for studying resistance of Prunus cerasifera Ehr. (Myrobalan plum) to Meloidogyne spp. Nematropica 23:41-48.

Felipe, A.J. 1989. Patrones para frutales de pepita y hueso. Ediciones Técnicas Europeas, S.A. Barcelona, España.

Felipe, A.J., R. Gella, J. Gómez-Aparisi, R. Socías, M. Carreras, and C. Palazón. 1990. Mejora genética: Obtención y selección de patrones para frutales de hueso, p. 115-120. In: Resultados de los proyectos de investigación terminados en 1990. Ministerio de Agr., Pesca y Alimentación, Madrid.

Fernández, C., J. Pinochet, and A. Felipe. 1993. Influence of temperature on the expression of resistance in six Prunus rootstocks infected with Meloidogyne incognita. Nematropica 23:195202.

García de Otazo, L. 1992. La problemática de la replantación de frutales en las comarcas frutícolas de Lleida. Fruticultura Profesional 44, p. 5-20.

Hansen, C. and H. Hartman. 1967. The use of indolebutyric acid and Captan in the propagation of clonal peach and peach-almond hybrid rootstocks by hardwood cuttings. Proc. Amer. Soc. Hort. Sci. 92:35-140.

Hoagland, D. and D.I. Arnon. 1950. The water culture method for growing plants without soil. California Agr. Expt. Sta., Circ. 347.
Hussey, R.S. and K.R. Barker. 1973. A comparison of methods of collecting inocula of Meloidogyne spp. including a new technique. Plant Dis. Rptr. 57:1025-1028.

Jenkins, W.R. 1964. A rapid centrifugal flotation technique for separating nematodes from soil. Plant Dis. Rptr. 48:692.

Lamberti, F. 1981. Plant nematode problems in the Mediterranean region. Helminthological Abstr. Series B. 50:145-166.

Malo, S.E. 1967. Nature of resistance to Okinawa and Nemaguard peach to the root-knot nematode Meloidogyne javanica. Proc. Amer. Soc. Hort. Sci. 90:39-46.

Marull, J. and J. Pinochet. 1991. Host suitability of Prunus rootstocks to four Meloidogyne species and Pratylenchus vulnus in Spain. Nematropica 21:185-195.

Marull, J., J. Pinochet, A. Felipe, and J.L. Cenis. 1994. Resistance verification in Prunus selections to a mixture of 13 Meloidogyne isolates and resistance mechanisms of a peach almond hybrid to M. javanica. Fund. Appl. Nematol. 17:85-92.

Marull, J., J. Pinochet, S. Verdejo, and A. Soler. 1991. Reaction of Prunus rootstocks to Meloidogyne incognita and M. arenaria in Spain. J. Nematol. 23(4S):564-569.

McKenry, M.V. 1989. Nematodes of stonefruit, California, p. 761-770. In: N.F. Childers and W.B. Sherman (eds.). The peach. Hort. Publ., Gainesville, Fla.

Nyczepir, A.P. 1991. Nematode management strategies in stone fruits in the United States. J. Nematol. 23:334-341.

Pinochet, J., A. Bello, and R. Rodríguez-Kabana. 1992. Nematodos en viveros frutales y cítricos, su introducción, dispersión y control. Fruticultura Profesional 44, p. 55-61.

Pinochet, J., S. Verdejo, and J. Marull. 1989 Evaluación de siete patrones de Prunus a tres especies de Meloidogyne en España. Nematropica 19:125-134.

Ramming, D.W. and O. Tanner. 1983. Nemared peach rootstock. HortScience 18:376.

Scotto La Massese, C. 1989. Les problèmes posés par les nématodes phytophages à l'amandier, $\mathrm{p}$ 33-88. In: A.J Felipe and R. Socías (eds.). Options méditerranéennes. Séminaire du GREMPA sur les porte-greffe de l'amandier. CIHEAM, Zaragoza, España.

Scotto La Massese, C., C. Grasselly, J.C. Minot, and R. Voisin. 1984. Différence de comportament de 23 clones et hybrides de Prunus à l'égard de quatre espèces de Meloidogyne. Revue de Nématologie 7:265-270.

Socías, R. 1990. Estado actual de los patrones frutales. Asociación Interprofesional para el Desarrollo Agrario, Zaragoza, España.

Wehunt, E.J. 1972. Influence of temperature on infection of Meloidogyne incognita acrita on Nemaguard peach. Plant Dis. Rptr. 56:305-308. 